\title{
Bioaktif Belimbing Wuluh (Averhoa bilimbi Linn.) Terhadap Kadar Formalin Dalam Tahu
}

\author{
Rinza Rahmawati Samsudin
}

Prodi D3 Teknologi Laboratorium Medik, FIK, Universitas Muhammadiyah Surabaya rinza_rahmawati@yahoo.com

\begin{abstract}
This study aims to determine the influence of the juice of

Tanggal Submit: 6 Mei 2018

Tanggal Review: 22 Mei 2018

Tanggal Publish Online:

28 Mei 2018 belimbing wuluh to the content of formalin in tofu and know the concentration of belimbing wuluh feeling is most effective in reducing the content of formalin in tofu. This study used a complete randomized design. The sample of this study was 30 tofu containing formalin which was divided into 6 groups. The weight of each sample is 15 grams.

The data of the research were analyzed by using anova test with 95\% confidence level, then Duncan test with 95\% confidence level. From the result of this research can be concluded that there is influence to formalin content in tofu. The content of formaldehyde in the highest to the lowest yields was found in soaking the belimbing wuluh with the concentrations is the group without treatment $(8269.40 \mathrm{mg} /$ $\mathrm{Kg}), 0 \%(1434.20 \mathrm{mg} / \mathrm{Kg}), 100 \%(762.00 \mathrm{mg} / \mathrm{Kg}), 25 \%$ (573.80 mg / Kg), 75\% (442.20 mg / kg), and 50\% (162.00 mg / $\mathrm{kg}$ ). The highest decrease in formaldehyde content in tofu by $98.40 \%$ occurred in the group K3 with the most effective 50\% concentration to decrease the formalin content in tofu.
\end{abstract}

Keyword : belimbing wuluh, tofu, formalin

\section{PENDAHULUAN}

Tahu merupakan bahan makanan yang banyak diminati oleh masyarakat di Indonesia. Hampir setiap hari tahu dapat dijumpai dalam menu makanan keluarga. Dari penelitian Karyasa (1993), diperoleh data bahwa 1 penduduk Indonesia mengkonsumsi tahu sebanyak 100 gram per hari. Berarti sekitar 2 juta kilogram tahu dibutuhkan setiap harinya.
Tahu merupakan salah satu sumber protein nabati. Makanan yang kaya akan kandungan protein memiliki kelemahan yaitu bahan tersebut mudah rusak. Sehingga, perlu upaya untuk mengawetkan agar dapat diterima konsumen dalam keadaan yang masih layak dikonsumsi. Usaha pengawetan yang bisa dilakukan sebenarnya cukup beragam mulai dari proses pengeringan, 
pendinginan, penambahan zat kimia, pengalengan, sampai dengan penggunaan radiasi. Namun, (produsen) lebih banyak memilih mengawetkan bahan makanan dengan cara menambahan zat kimia bahan pengawet salah satunya yaitu menggunakan formalin.

Bahan pengawet merupakan bahan tambahan makanan yang dibutuhkan untuk mencegah aktivitas mikroorganisme yang terjadi sesuai dengan pertambahan waktu, agar kualitas makanan senantiasa terjaga. Tujuan produsen menambahkan bahan pengawet ke dalam makanan adalah untuk memperpanjang masa simpan dan mencegah pertumbuhan mikroba perusak pangan yang dapat menurunkan mutu pangan.Yang dimaksud bahan pengawet adalah bahan tambahan makanan yang mencegah atau menghambat fermentasi pengasaman atau peruraian lain terhadap makanan yang disebabkan oleh mikroorganisme (Nuryasin, 2006).

Menurut Peraturan Menteri Kesehatan (MenKes) Nomor 1168/MenKes/PER/X/1999, formalin merupakan bahan kimia yang penggunaannya dilarang untuk produk makanan (Nuryasin, 2006). Tetapi masih banyak para produsen yang menggunakan bahan formalin untuk mengawetkan makanan. Alasan produsen menggunakan formalin sebagai pengawet makanan karena mudah didapat, harga relatif murah dan mudah dalam penggunaannya.

Formalin memiliki unsur aldehida yang bersifat mudah bereaksi dengan protein, karenanya ketika disiramkan ke makanan seperti tahu, formalin akan mengikat unsur protein mulai dari bagian permukaan tahu hingga terus meresap kebagian dalamnya. Dengan matinya protein setelah terikat unsur kimia dari formalin maka bila ditekan tahu terasa lebih kenyal, Selain itu protein yang telah mati tidak akan diserang bakteri pembusuk yang menghasilkan senyawa asam, Itulah sebabnya tahu atau makanan lainnya menjadi lebih awet (Anonim, 2006)

Pemakaian formalin didalam makanan sangat tidak dianjurkan karena didalam formalin terkandung zat formaldehid yang didalam tubuh bersifat racun. Kandungan formalin yang tinggi didalam tubuh akan 
menyebabkan iritasi lambung, alergi, bersifat karsinogenik dan bersifat mutagen serta orang yang mengkonsumsinya akan mengalami muntah, diare dan kencing akan merangsang terjadinya iritasi hidung, tenggorokan dan mata (Winarno, 1995).

Jika formalin termakan, dalam jangka pendek tidak menyebabkan keracunan, tetapi jika tertimbun di atas ambang batas dapat mengganggu kesehatan. Ambang batas yang aman adalah 1 miligram perliter (Kompas, 2005). Sedangkan International Proggrame on Chemical Safety menetapkan bahwa batas toleransi yang dapat diterima dalam tubuh maksimum $0,1 \mathrm{mg}$ perliter (Harmoni, 2006).

Resiko penambahan bahan pengawet formalin dalam makanan sangat besar terutama bagi kesehatan. Sehingga perlu diadakan upaya untuk menghilangkan atau menurunkan kadar formalin dalam makanan tersebut secara alami. Salah satu alternative yang dapat dilakukan adalah menggunakan perasan buah belimbing wuluh Averrhoa bilimbi (Linn.) bercampur darah dan apabila terhirup

Di Indonesia buah belimbing wuluh sangat mudah diperoleh dengan harga yang sangat terjangkau serta mudah untuk dikembang biakan. Namun, pemanfaatan buah belimbing wuluh kurang optimal. Masyarakat Indonesia biasanya menggunakan buah belimbing wuluh hanya sebagai penambah rasa pada masakan.

Belimbing wuluh adalah kelompok tanaman Oxalidaceae, yang banyak dimanfaatkan buahnya. Buah belimbing wuluh mengandung banyak air dan rasanya asam segar. Namun, karena rasa yang asam maka belimbing wuluh jarang dimanfaatkan oleh masyarakat sebagai tanaman obat. Buah belimbing wuluh mempunyai beberapa kandungan senyawa kimia yang bersifat asam seperti, asam oksalat, asam sitrat, asam tartrat dan asam suksinat, asam format, glukosit, flavonoid, kalium oksalat, minyak menguap, dan pektin. (Hembing, 2008). Tahu. Surabaya : The Journal of Muhamadiyah Medical Laboratory Technologist. Vol: 1, No.2 (177-186). 


\section{METODE PENELITIAN}

\section{Bahan}

Bahan pada penelitian ini menggunakan tahu, belimbing wuluh, aquadest, formalin.

\section{Alat}

Blender, SpektrofotometerUV-vis, Timbangan analitik digital, Baskom, Kain flannel, Pisau, Botol gelap, Labu ukur, Gelas ukur, Erlemeyer, Pipet tetes, Kertas saring WHATMAN 40.

\section{Prosedur Penelitian}

a. Pembuatan Tahu Berformalin

1. Menyiapkan tahu yang tidak mengandung formalin,

2. Menyiapkan larutan formalin dengan kosentrasi $2 \% \mathrm{v} / \mathrm{v}$.

3. Tahu yang tidak mengandung formalin direndam dalam larutan formalin $2 \% \quad \mathrm{v} / \mathrm{v}$ selama 60 menit.

b. Pembuatan Perasan Belimbing Wuluh Segar

1. Buah belimbing wuluh segar dicuci bersih dengan air mengalir, lalu ditiriskan hingga kering diatas kain flanel.

2. Buah belimbing wuluh segar tersebut dipotong kecil-kecil kemudian dihaluskan dengan blender tanpa penambahan aquadest.
3. Hasil blenderan diperas dengan menggunakan kain flannel

4. Kosentrasi hasil perasan belimbing wuluh yang didapat adalah $100 \%$

c. Perhitungan Pembuatan Berbagai Kosentrasi Perasan Belimbing Wuluh

1. Dari kosentrasi perasan belimbing wuluh $100 \%$ diencerkan dengan penambahan aqudest, pembuatan berbagai kosentrasi belimbing wuluh sesuai dengan perhitungan di bawah ini:

a. Kosentrasi belimbing wuluh $0 \%$ volume $1000 \mathrm{ml}$ didapat dari aquadest sebanyak 1000ml tanpa penambahan perasan belimbing wuluh.

b. Kosentrasi belimbing wuluh $25 \%$ volume 1000 $\mathrm{ml}$ didapat dari, $\frac{25}{100} \times 1000 \mathrm{ml}=$ $250 \mathrm{ml}$

(extrak belimbing wuluh 100\%) di tambah dengan aquadest sebanyak $750 \mathrm{ml}$.

c. Kosentrasi belimbing wuluh $50 \%$ volume 1000 $\mathrm{ml}$ didapat dari, $\frac{50}{100} \times 1000=500 \mathrm{ml}$ (extrak 
belimbing wuluh 100\%) di tambah dengan aquadest sebanyak $500 \mathrm{ml}$.

d. Kosentrasi belimbing wuluh $75 \%$ volume 1000 $\mathrm{ml}$ didapat dari, $\frac{75}{100} \times 1000 \mathrm{ml}=$ $750 \mathrm{ml}$

(extrak belimbing wuluh 100\%) ditambah dengan aquadest sebanyak $250 \mathrm{ml}$.

e. Kosentrasi belimbing wuluh $100 \%$ volume 1000 $\mathrm{ml}$ didapat dari hasil perasan belimbing wuluh tanpa penambahan air.

2. Kemudian dikocok hingga homogen.

3. Sediaan yang diperoleh dapat disimpan dalam wadah botol gelap bertutup rapat.

d. Prosedur Perlakuan Bahan Uji

1. Tahu non formalin diperoleh dari pabrik tahu yang berada di kawasan Sepanjang dipotong dengan berat \pm 15 gram

2. Menyediakan 30 wadah yang berisi larutan perasan belimbing wuluh dalam berbagai kosentrasi

3. Tahu dimasukan kedalam wadah yang berisi larutan perasan belimbing wuluh dalam berbagai kosentrasi (posisi tahu dalam keadaan terendam seluruhnya)

4. Perendaman tahu dilakukan selama \pm 15 menit

5. Setelah 15 menit tahu ditiriskan

e. Prosedur Pengujian Formalin Dengan Metode Spektrofotometri

1. Bahan yang akan diuji (tahu) timbang sebanyak 5 gram kemudian dihancurkan

2. Ditambahkan aquadest sebanyak 100ml kemudian diaduk selama 6 jam

3. Setelah diaduk selama 6 jam bahan di saring dengan kertas WHATMAN 40 sehingga diperoleh filtrat yang jernih

4. Mengukur nilai adsorbansi sample dan larutan standart formalin dengan alat Spektrofotometri UV pada panjang gelombang $560 \mathrm{~nm}$

\section{HASIL}

Hasil penelitian dengan menggunakan 30 sampel yang dibagi kedalam 6 kelompok pada table 1 menunjukkan bahwa perendaman perasan belimbing wuluh dengan konsentrasi $50 \% \quad(162.00 \quad$ a) memberikan pengaruh terbesar dan 
tahu tanpa perlakuan atau tanpa perendaman belimbing wuluh memberikan pengaruh yang terkecil (1434.20 c). Namun, konsentrasi perasan $25 \%(573.80$ b) dan $100 \%$ $(762.00$ b) tidak berbeda nyata. Perasan belimbing wuluh dengan konsentrasi $75 \%$ memiliki pengaruh antara (442.20 ab). Dari hasil perendaman dalam berbagai konsentrasi perasan belimbing wuluh menunjukkan bahwa konsentrasi perasan $50 \%$ penurunan kandungan formalin yang paling rendah dan efektif.

Tabel 1. Penurunan Formalin dalam Tahu

\begin{tabular}{|l|l|l|l|}
\hline Grup & $\begin{array}{l}\text { Kadar } \\
\text { perasan } \\
\text { belimbing } \\
\text { wuluh } \\
\text { (v/v) }\end{array}$ & $\begin{array}{l}\text { Kadar } \\
\text { formalin } \\
(\mathbf{m g} / \mathbf{K g})\end{array}$ & $\begin{array}{l}\text { Penurunan } \\
\text { formalin } \\
(\%)\end{array}$ \\
\hline K0 & $\begin{array}{l}\text { kontrol } \\
\text { non } \\
\text { perlakuan }\end{array}$ & $8269.40 \mathrm{~d}$ & $0 \%$ \\
\hline K1 & $0 \%$ & $1434.20 \mathrm{c}$ & $83.65 \%$ \\
\hline K2 & $25 \%$ & $573.80 \mathrm{~b}$ & $93.06 \%$ \\
\hline K3 & $50 \%$ & $162.00 \mathrm{a}$ & $98.04 \%$ \\
\hline K4 & $75 \%$ & $442.20 \mathrm{ab}$ & $94.65 \%$ \\
\hline K5 & $100 \%$ & $762.00 \mathrm{~b}$ & $90.78 \%$ \\
\hline
\end{tabular}

Ket: Angka yang diikuti dengan huruf menunjukkan beda nyata berdasarkan uji duncan $\alpha=0,05$
Penambahan

perasan

belimbing wuluh dengan konsentrasi 0\% kedalam pengolahan tahu menunjukan penurunan kandungan formalin kandungan tahu yang paling rendah sebesar $82.65 \%$. Sedangkan penambahan perasan belimbing wuluh dengan konsentrasi 50\% menunjukan penurunan kandungan formalin dalam tahu yang paling tinggi yaitu sebesar $98.04 \%$. Dengan demikian penurunan kandungan formalin terbesar dalam tahu sebesar 98.40\% sehingga dapat disimpulkan, tahu berformalin yang direndam dengan konsentrasi belimbing wuluh $50 \%$ paling efektif untuk menurunkan kandungan formalin dalam tahu dapat dilihat pada Grafik1.

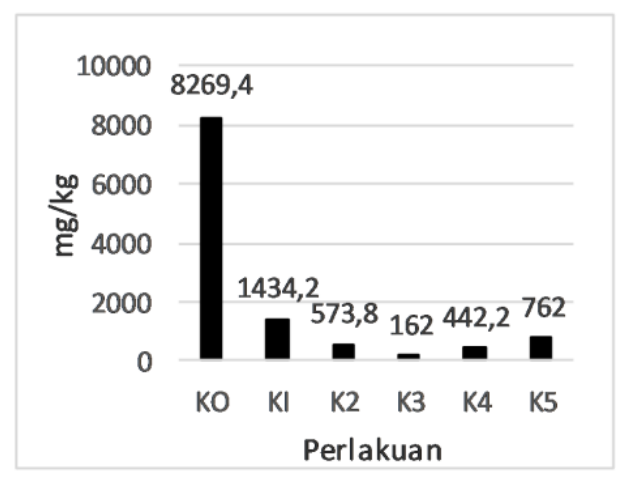

Grafik 1. Kandungan formalin dalam tahu 
PEMBAHASAN

\section{A. Pengaruh Perasan Buah} Belimbing Wuluh Terhadap Kandungan Formalin Pada Tahu

Pengolahan bahan makanan

dengan belimbing wuluh dapat menjadi alternatif dalam upaya menghilangkan formalin dalam bahan makanan (Wikanta, 2011). Belimbing wuluh mengandung kadar asam yang tinggi dengan nilai $\mathrm{pH} 2$ 4 (Morton dan Miami, 1987; Orwa et al. 2009). Salah satu kandungan pada buah belimbing wuluh adalah asam sitrat. Asam sitrat merupakan komponen senyawa alam yang banyak terdapat pada berbagai jenis tanaman terutama buah-buahan. Asam sitrat merupakan senyawa asam organik lemah. Salah satu sifat dari asam sitrat yaitu sebagai pengelat. Keasaman asam sitrat didapat dari tiga gugus karboksil $\mathrm{COOH}$ yang dapat melepas proton dalam larutan yaitu tiap molekul mengandung tiga gugus karboksil dengan 1 gugus hidroksil yang terikat pada atom karbon yang ada ditengah.

Asam karboksilat adalah golongan asam organic alifatik (rantai terbuka) yang memiliki gugus fungsional karboksil (yang dilambangkan dengan $\mathrm{COOH}^{-}$).

Asam karboksilat yang mengandung C1 sampai $\mathrm{C} 4$ berbentuk cairan encer dan larut sempurna dalam air. Dalam pelarut air sebagian molekulnya terionisasi dengan melepas atom $\mathrm{H}$ menjadi ion $\mathrm{H}^{+}$(Riawan (1990). Jika asam karboksilat bereaksi dengan alkohol akan membentuk ester reaksi ini disebut esterifikasi (Hart, 2003). Ester merupakan senyawa turunan dari asam karboksilat dengan mengganti gugus hidroksil -OH dengan -OR1 sehingga memiliki rumus R-COOR1. Dari reaksi tersebut menunjukan kandungan formalin dalam tahu akan menurun setelah direndam dengan perasan belimbing wuluh dibandingkan dengan air dan tanpa perlakuan. Penurunan kadar formalin disebabkan karena terurai menjadi ester dan air (Hart, 2003).

Riawan

mengemukakan bahwa pemisahan aldehid dalam suatu campuran, di antaranya dapat dilakukan dengan asam. Hasil penelitian pada tahu yang direndam dalam perasan belimbing wuluh menunjukkan bahwa terjadi penurunan kadar formalin sampai $98 \%$. Penelitian ini 
didukung oleh penelitian Wilson dan Goulding (Eds.), (1989) dalam Wikanta (2011) yang menyebutkan bahwa belimbing wuluh sebagai sumber asam dalam pengolahan udang putih berformalin telah mengkatalisis proses pelepasan ikatan formalin dan protein. Dalam beberapa reaksi kimia, misalnya hidroslisis, asam dapat berfungsi sebagai katalis. Hasil penelitian ini sejalan dengan penelitian (Wikanta, 2011).

Pengawet formalin memiliki unsur aldehida yang bersifat mudah bereaksi dengan protein. Ketika formalin disiramkan ke makanan seperti tahu, formalin akan mengikat unsur protein mulai dari bagian permukaan tahu hingga terus meresap kebagian dalamnya. Dengan matinya protein setelah terikat unsur kimia dari formalin maka bila ditekan tahu terasa lebih kenyal. Selain itu protein yang telah mati tidak akan diserang bakteri pembusuk yang menghasilkan senyawa asam. Sehingga tahu atau makanan lainnya menjadi lebih awet (Anonim, 2006).

Mekanisme formalin sebagai pengawet adalah jika formaldehid bereaksi dengan protein, sehingga membentuk rangkaian-rangkaian antara protein yang berdekatan. Akibat dari reaksi tersebut, protein mengeras dan tidak dapat larut. Hal inilah yang menyebabkan formalin digunakan sebagai pengawet makanan terutama yang mengandung protein (Cahyadi, 2006).

Perendaman tahu dalam formaldehid menyebabkan sebagian besar protein sitoplasma terkoagulasi. Protein yang berikatan dengan formaldehid menyebabkan kualitas protein menurun dan bila dikonsumsi, ada sebagian kecil formaldehid bebas yang akan terikat dalam metabolisme tubuh.

\begin{tabular}{|c|c|c|}
\hline $\begin{array}{l}\text { B. Kosen } \\
\text { Efektif D }\end{array}$ & $\begin{array}{c}\text { Yang } \\
\text { Menu }\end{array}$ & $\begin{array}{r}\text { Paling } \\
\text { Irunkan }\end{array}$ \\
\hline Kandungan I & Formalin & \\
\hline Hasil & penelitian & ini \\
\hline menunjukan & bahwa & terjadi \\
\hline penurunan & kandungan & formalin \\
\hline dalam & setelah & ilakukan \\
\hline perendaman & dalam & perasan \\
\hline belimbing & wuluh. & ant \\
\hline
\end{tabular}
konsentrasi perasan belimbing wuluh $50 \%$ menunjukkan hasil yang paling optimal dibandingkan konsentrasi 75 dan $100 \%$. Hal ini menunjukkan bahwa konsentrasi belimbing wuluh $50 \%$ paling efektif. Hasil penurunan 
kandungan formalin yang efektif tersebut dipengaruhi dengan jumlah konsetrasi belimbing wuluh. Faktor faktor yang mempengaruhi laju reaksi adalah konsentrasi, kelarutan, luas permukaan kontak, temperatur, katalisator. Larutan dengan konsentrasi yang besar (pekat) mengandung partikel yang lebih rapat, jika dibandingkan dengan larutan encer. Semakin tinggi konsentrasi berarti semakin banyak molekul-molekul dalam setiap satuan luas ruangan, akibatnya tumbukan antar molekul makin sering terjadi dan reaksi berlangsung semakin cepat.

Kosentrasi $50 \%$ memiliki kerapatan molekul yang lebih rendah daripada $75 \%$ dan $100 \%$. Kerapatan molekul pada konsentrasi 50\% cukup untuk mendukung optimalnya laju reaki dengan formalin pada tahu. Kosentrasi $100 \%$ kurang efektif untuk menurunkan kadar formalin karena memiliki kerapatan molekul yang terlalu rapat.

Namun dari hasil penelitian ini menunjukkan bahwa perlakuan perendaman dengan perasan belimbing wuluh tidak dapat menghilangkan semua kadar formalin pada tahu. Makanan berformalin akan beracun jika didalamnya mengandung sisa formaldehid bebas. Sisa formaldehid bebas (yang tidak bereaksi) hampir selalu ada dan sulit dikendalikan. Pada saat formalin di pakai mengawetkan makanan, gugus aldehid bereaksi dengan protein dalam makanan. Jika semua formalin habis bereaksi, sifat racun formalin akan hilang. Protein makanan yang telah bereaksi dengan formalin menjadi tidak beracun, namun nilai gizi makanan itu menjadi rendah, menjadi sukar dihidrolisis oleh enzim pencernaan (Nurachman, 2005) dalam (Raffy 2006).

\section{KESIMPULAN}

Tahu formalin yang direndap dengan perasan belimbing wuluh dapat menurunkan kadar formalin. Penurunan kandungan formalin terbesar dalam tahu sebesar $98.40 \%$. Kosentrasi belimbing wuluh yang paling efektif untuk menurunkan kandungan formalin dalam tahu adalah $50 \%$. 


\section{DAFTAR PUSTAKA}

Anonim. 2006. Formalin Bukan Formalitas, Jakarta: Charoen Pokphand Indonesia. Vol VII (73): 1-8

Cahyadi. W. 2006. Kedelai Khasiat dan Teknologi. Bandung. Bumi Aksara.

Hart, H. 2003. Kimia Organic. Jakarta: Erlangga

Karyasa, I.W. 2000. Bangga Makan Tahu Tempe. Forum Diskusi Indonesia. Jakarta: Berlin

Nuryasin, A. 2006. Bahaya Formalin.

http://ikap=kdk.com/arpan/cont ent/view/III Orwa et al. 2009. Averrhoa bilimbi L. Agroforestry Database 4.0. [online].

Orwa et al. 2009. Averrhoa bilimbi L. Agroforestry Database 4.0.

Peraturan Menteri Kesehatan RI No. 722/MENKES/PER/IX/1988 tentang Bahan Tambahan Makanan. Departemen Kesehatan RI
Raffi, O. 2006. Jika Dicerna Formalin Tidak Berbahaya. [Online] forum komunitas www.pitunet.com/lihatopini.php?=2006/01/20012006/ 35815.

Riawan, S. 1990. Kima Organik. Edisi ke-1. Jakarta: Binarupa Aksara

Wikanta, W. Abdurrajak, Y. Sumarno. Amin, M. 2011. Pengaruh Penambahan Belimbing Wuluh (Averrhoa Bilimbi L.) Dan Perebusan Terhadap Kadar Residu Formalin Dan Profil Protein Udang Putih (Letapenaeus Vannamei) Berformalin Serta Pemanfaatannya Sebagai Sumber Pendidikan Gizi Dan Keamanan Pangan Pada Masyarakat.

Wilson K and Goulding K.H (Eds.), 1986. Biologist's Guide to principle and Techniques of Practical Biochemistry. London: Edward Arnold Publisher, Ltd. 